\title{
Correction to: State-organized crime and the killing of wolves in Norway
}

\author{
Ragnhild Sollund ${ }^{1}$. David R. Goyes ${ }^{1}$
}

Published online: 27 July 2021

(c) Springer Science+Business Media, LLC, part of Springer Nature 2021

\section{Correction to: Educational Psychology Review https://doi.org/10.1007/s12117-021-09420-3}

Through an inadvertent error, the authors of the article 'State-organized crime and the killing of wolves in Norway' (published online first on 29 June 2021, https:// doi.org/10.1007/s12117-021-09420-3) did not include the source of funding for this research. The authors, Ragnhild Sollund and David R. Goyes, apologize for any inconvenience this error may have caused the reader and state that this study was produced as part of the project "Criminal justice, wildlife conservation and animal rights in the Anthropocene-CRIMEANTHROP" in the Department of Criminology and Sociology of Law, University of Oslo, funded by the Granting Committee for the Humanities and Social Sciences (FRIPRO) of the Research Council of Norway, project number 289285 .

The original article has been corrected.

Publisher's note Springer Nature remains neutral with regard to jurisdictional claims in published maps and institutional affiliations.

The original article can be found online at https://doi.org/10.1007/s12117-021-09420-3.

Ragnhild Sollund

ragnhild.sollund@jus.uio.no

David R. Goyes

d.r.goyes@jus.uio.no

1 Department of Criminology and Sociology of Law, University of Oslo, Oslo, Norway 